QUALITY

Volume 8, Nomor 2, 2020, 291-302

\title{
Pengaruh Hidden Curriculum Berbasis Pesantren terhadap Pembentukan Akhlaqul Karimah Siswa di SMK Cordova Kajen Tahun 2019
}

\author{
Nur Laila Syarifah \\ IAIN Kudus, Indonesia \\ nurlaila2360@gmail.com
}

\begin{abstract}
Abstrak
Penelitian ini bertujuan untuk mendeskripsikan: (1) pelaksanaan hidden curriculum berbasis pesantren dan pembentukan akhlaqul karimah siswa di SMK Cordova Kajen tahun 2019, (2) seberapa besar pengaruh hidden curriculum berbasis pesantren terhadap pembentukan karakter akhlaqul karimah siswa di SMK Cordova Kajen Tahun 2019. Metode penelitian yang digunakan dalam penelitian ini yaitu penelitian kuantitatif dengan jenis penelitian lapangan (field research). Penentuan sampel menggunakan random sampling, yang diambil $20 \%$ dari jumlah populasi 312 siswa kelas X SMK Cordova Kajen, didapatkan sampel sebanyak 62 siswa. Teknik pengumpulan data melalui wawancara, kuesioner, dan observasi. Sedangkan analisis yang dilakukan dengan mengggunakan analisis regresi linier sederhana. Hasil penelitian menunjukkan bahwa: (1) hidden curriculum berbasis pesantren dan pembentukan akhlaqul karimah siswa di SMK Cordova Kajen tahun 2019 dalam kategori baik, dengan nilai 89,77, dan cukup baik, dengan nilai 85,56 serta (2) terdapat pengaruh yang positif dan signifikan antara hidden curriculum berbasis pesantren dengan pembentukan karakter akhlaqul karimah siswa di SMK Cordova Kajen tahun 2019, di mana apabila hidden curriculum meningkat sebesar 1 satuan maka akhlaqul karimah siswa akan meningkat sebesar 0,439. Sehingga hidden curriculum berbasis pesantren memiliki pengaruh sebesar $19,27 \%$ terhadap pembentukan karakter akhlaqul karimah siswa di SMK Cordova Kajen tahun 2019.
\end{abstract}

Kata Kunci: Hidden Curriculum; Pesantren; Akhlaqul Karimah 


\begin{abstract}
This study aimed to describe: (1) the implementation of the hidden curriculum pesantren based and noble character building of student at SMK Cordova Kajen in 2019, (2) how big the effect of hidden curriculum pesantren based against noble character building of student at SMK Cordova Kajen in 2019. The research uses a quantitative method, and this research includes the study of field research. The samples using random sampling, was taken of $20 \%$ of population 312 student $X$ grade of SMK Cordova at Kajen, obtained a sample of 62 student. The technique of collecting data through interview, questionnaire, and observation. While the analysis is done by simple linier regression. The results showed that: (1) the hidden curriculum pesantren based and noble character building of student at SMK Cordova Kajen in 2019 in the category good at 89,77 and good enough at 85,65, and (2) there is a positive and significant influence of hidden curriculum pesantren based against noble character building of student at SMK Cordova Kajen in 2019, as if the score of hidden curriculum increased by 1 unit, the noble character of student will increase by 0,439. So the hidden curriculum of pesantren based contributes $19,27 \%$ of the noble character of student at SMK Cordova Kajen in 2019.
\end{abstract}

Keywords: The Hidden Curriculum; Pesantren; Noble Character

\title{
A. Pendahuluan
}

Undang-Undang Nomor 20 tahun 2003 tentang sistem pendidikan nasional, disebutkan bahwa pendidikan nasional berfungsi mengembangkan kemampuan dan membentuk watak serta peradaban bangsa yang bermartabat dalam rangka mencerdaskan kehidupan bangsa, bertujuan untuk berkembangnya potensi siswa agar menjadi manusia yang beriman dan bertakwa kepada Tuhan Yang Maha Esa, berakhlak mulia, sehat, berilmu, cakap, kreatif, mandiri, dan menjadi warga Negara yang demokratis serta tanggung jawab. Jadi sekolah sebagai sebuah lembaga dalam mewujudkan fungsi pendidikan nasional bukan hanya tempat di mana siswa mempelajari berbagai mata pelajaran dengan tujuan memperoleh nilai yang baik kemudian lulus dan mendapatkan ijazah. Sekolah sebagai lembaga pendidikan juga memiliki peranan strategis dalam mewujudkan peserta didik yang berakhlaqul karimah yang mampu mengamalkan pengalaman keagamaannya dalam kehidupan sehari-hari. 


\section{Nur Laila Syarifah}

Namun saat ini pendidikan di lingkungan sekolah dinilai gagal dalam mengatasi degradasi moral. Akhlaqul karimah menjadi barang mewah bagi kalangan pelajar. Sekolah dinilai jauh lebih mengedepankan pendidikan yang bersifat akademik dari pada pendidikan karakter/akhlak. Sehingga yang terjadi adalah anjloknya moralitas pelajar. Sekolah harus berkontribusi dalam upaya pembentukan karakter siswa. Salah satu hal yang menyebabkan merosotnya nilainilai moral dan karakter siswa di SMK Cordova adalah kurang optimalnya peran warga sekolah dalam mengimplementasikan pendidikan karakter karena di SMK sendiri lebih mengedepankan kognitif siswa disbanding afeksinya. Hal ini sama seperti yang diungkapkan dalam hasil penelitian yang dilakukan oleh Tutik Ningsih (2015: 10) bahwa factor-faktor yang mempengaruhi merosotnya moral siswa diantaranya adalah belum adanya peraturan yang mengatur proses integrasi nilainilai karakter bagi siswa, kurangnya pemahaman guru tentang mengintegrasikan nilai karakter dan moral ke dalam pembelajaran, belum optimalnya peran warga sekolah dalam implementasi pendidikan karakter dan kurangnya media pembelajaran yang mendukung pelaksanaan proses pembelajaran berbasis pendidikan karakter.

Tidak mudah memang untuk mengubah perilaku dan karakter siswa. Oleh karena itu usaha maksimal harus terus diupayakan oleh pengelola sekolah yaitu kepala sekolah, guru dan tenaga kependidikan, dengan bekerjasama menciptakan budaya sekolah yang baik, melalui pemanfaatan sumber belajar, sarana dan prasarana sekolah dengan upaya tersebut akan lebih mudah terwujud. Selanjutnya, diharapkan siswa dapat memperoleh pengalaman di sekolah untuk mengembangkan kreativitasnya dengan bimbingan para guru.

Hal tersebut senada dengan yang diungkapkan oleh Caswita (2013: 51) bahwa yang menjadi sumber utama dari hidden curriculum itu sendiri adalah guru. Demikian pula yang diungkapkan oleh Semper (2018) dalam artikelnya yang berjudul Revealing the Hidden Curriculum in Higher Education bahwa the concept of the hidden curriculum (HC) defined as 'what is implicit and embedded in 


\section{Nur Laila Syarifah}

educational experiences in contrast with the formal statements about curricula and the surface features of educational interaction' in arguing that it is impossible to extirpate the teacher and student from the learning equation. Dalam hal ini guru harus menjadi teladan bagi siswanya. Guru merupakan sumber belajar dan kurikulum yang paling efektif dalam menyampaikan materi pembelajaran. Perbuatan, perkataan, penampilan, dan cara berinteraksi dengan orang lain akan selalu dicontoh oleh siswa.

Berdasarkan hasil penelitian yang dilakukan Pratiwi (2017: 233) karakter siswa dipengaruhi oleh hidden curriculum sebesar 52,7\% sedangkan 47,3\% dipengaruhi oleh faktor lain. Pentingnya hidden curriculum terletak pada keberhasilannya. Di dalam artikelnya Halid (2019: 143) menyebutkan bahwa fungsi hidden curriculum berbasis pesantren adalah menumbuhkan karakter yang unggul meliputi sikap tawadlu, rendah hati, taat, beriman, ikhlas, tanggung jawab, mandiri, kesederhanaan, kebebasan berpendapat, berorganisasi, sopan santun, menghormati dan lainnya.

Dari penjelasan diatas menunjukkan bahwa pentingnya perhatian terhadap pelaksanaan hidden curriculum dalam upaya pembentukan karakter akhlaqul karimah siswa, sehingga dihasilkan anak didik yang cerdas dan berwawasan serta mempunyai dan menerapkan nilai-nilai karakter akhlaqul karimah, di mana salah satu media penyampaian nilai karakter tersebut kepada anak didik adalah melalui pelaksanaan pendidikan agama Islam.

Adapun berdasarkan wawancara yang peneliti lakukan dengan Guru BK persoalan negatif yang berkaitan dengan moral siswa di SMK Cordova diantaranya adalah bolos saat jam pelajaran, baju tidak dimasukkan, terlambat ke sekolah, rambut gondrong, berhias berlebihan, merokok di lingkungan sekolah, tidak mengikuti upacara, membuat izin palsu, berbicara kasar dengan guru, dan paling berat adalah tawuran antar sekolah. 


\section{Nur Laila Syarifah}

Dengan adanya permasalahan tersebut sekolah perlu membekali siswa pengetahuan dan pengalaman keagamaan. Misalnya dengan cara menerapkan sekolah yang berbasis pesantren, melalui pembiasaan kegiatan-kegiatan keagamaan, dan keteladanan guru sehingga mampu membentuk karakter akhlaqul karimah. Agar siswa mempunyai bekal untuk menghadapi kemajuan teknologi dan krisis moral yang terjadi saat ini dengan tetap perpegang teguh terhadap keyakinan agama yang dimilikinya.

Dalam perspektif ini, upaya membentuk karakter akhlaqul karimah siswa dapat dilakukan melalui hidden curriculum berbasis pesantren. Karena hidden curriculum dilakukan secara rutin di sekolah, sehingga secara otomatis siswa terbiasa dalam melaksanakan kegiatan keagamaan dan secara tidak langsung dapat membentuk karakter akhlaqul karimah siswa.

Akhlak merupakan fondasi utama dalam pembentukan pribadi manusia seutuhnya (Firdaus, 2017: 55). Di dalam Islam untuk menguji akhlak itu baik atau buruk ukuran atau rujukannya adalah al-Qur'an dan as-Sunnah. Perbuatan apa saja yang diperintahkan dan dianjurkan dalam al-Qur'an dan as-Sunnah adalah merupakan akhlak yang baik (Syafe'I, 2014: 139). Dengan mempunyai perilaku keagamaan yang baik, siswa akan menjadi pribadi yang berakhlaqul karimah, sesuai dengan tujuan pendidikan nasional. Hal ini selaras dengan pendapat Deswita (2010: 92) bahwa manusia akan menjadi sempurna jika mempunyai akhlak terpuji serta menjauhkan segala akhlak tercela. Sehingga secara tidak langsung hidden curriculum dapat mewujudkan tujuan pendidikan nasional melalui pembentukan perilaku keagamaan kepada siswa. Selain baik dari segi akhlak, hidden curriculum juga dapat meningkatkan kompetensi keagamaan siswa melalui praktek keagamaan yang dilakukan sehari-hari. Hal itu pula yang juga dapat mendukung tercapainya tujuan pendidikan.

Salah satu lembaga yang melaksanakan hidden curriculum berbasis pesantren yaitu SMK Cordova Kajen. Pelaksanaan hidden curriculum berbasis pesantren pada lembaga ini lebih menekankan pembiasaan beribadah dan kegiatan 


\section{Nur Laila Syarifah}

keagamaan lainnya, sebagai bentuk praktik dari Pendidikan Agama Islam sehingga dapat membentuk karakter akhlaqul karimah siswa. Beberapa bentuk hidden curriculum berbasis pesantren yang terdapat di SMK Cordova Kajen adalah pembiasaan berjabat tangan kepada guru-guru ketika memasuki sekolah, pelaksanaan sholat dhuha, pelaksanaan sholat berjama'ah, membaca do'a dan Asma'ul Husna sebelum memulai pelajaran jam pertama dan sebelum bel pulang sekolah, istighosah dan do'a bersama menjelang ujian, serta Ziarah ke makam para wali terdekat ketika haul.

Guna mengetahui seberapa besar pengaruh hidden curriculum berbasis pesantren terhadap pembentukan akhlaqul karimah siswa di SMK Cordova tahun 2019, maka dipandang perlu mengadakan penelitian ini lebih lanjut dengan mendeskripsikan dahulu tentang bagaimana pelaksanaan hidden curriculum berbasis pesantren dan pembentukan akhlaqul karimah siswa di SMK Cordova tahun 2019.

Penelitian ini menggunakan pendekatan kuantitatif dengan data berwujud angka hasil kuesioner pelaksanaan hidden curriculum dan pembentukan akhlaqul karimah pada siswa kelas X di SMK Cordova Kajen tahun 2019. Penelitian ini termasuk jenis penelitian field research (Fathoni, 2006: 96), karena penelitian dilakukan langsung di SMK Cordova Kajen.

Populasi untuk penelitian ini adalah seluruh siswa kelas X di SMK Cordova Kajen, yakni sebanyak 312 siswa. Sedangkan sampel dalam penelitian ini dengan menggunakan teknik random sampling, yakni pengambilan sampel dari populasi dilakukan secara acak (Sugiyono, 2015: 120) dengan ukuran sampelnya menggunakan teori dari Arikunto (1998: 107) yaitu apabila jumlah populasi lebih besar dari 100 maka diambil antara 10\%-15\% atau 20\%-25\%. Berdasarkan teori tersebut maka peneliti mengambil sampel sebanyak 20\% dari seluruh siswa kelas X dan diperoleh sampel sebanyak 62 siswa. 
Untuk memperoleh data-data yang diperlukan dalam penelitian ini, peneliti menggunakan teknik pengumpulan data berupa; (1) wawancara, yang kami lakukan kepada Waka. Kurikulum dan guru mata pelajaran PAI untuk mengetahui bagaimana pelaksanaan hidden curriculum dan pembentukan akhlaqul karimah siswa, (2) kuesioner, yang peneliti gunakan untuk menggali data berupa angka tentang pelaksanaan hidden curriculum dan pembentukan akhlaqul karimah, yang mana kuesioner yang peneliti buat menggunakan skala likert, serta (3) observasi, peneliti menggunakan jenis observasi non partisipan untuk memperoleh data melalui pengamatan langsung kegiatan hidden curriculum yang telah diterapkan di SMK Cordova Kajen.

Analisis data dilakukan dengan mendeskripsikan variabel hidden curriculum dan akhlaqul karimah menggunakan analisis regresi linier sederhana. Analisis data penelitian ini juga menggunakan bantuan program SPSS for Windows versi 17.0.

\section{B. Pembahasan}

Hasil dari data nilai angket kemudian dibuat tabel penskoran hasil angket dari variabel X yaitu Hidden Curriculum dan variabel Y yaitu Akhlaqul Karimah diperoleh interval kategori dari masing-masing variabel sebagai berikut:

Tabel 1. Nilai Interval Hidden Curriculum (HC) dan Akhlaqul Karimah

\begin{tabular}{cccc}
\hline No. & Interval HC & Kategori & Interval AK \\
\hline 1 & $98,75-109$ & Sangat Baik & $101,25-115$ \\
\hline 2 & $87,5-97,75$ & Baik & $86,5-100,25$ \\
\hline 3 & $76,25-86,5$ & Cukup Baik & $71,75-85,5$ \\
\hline 4 & $65-75,25$ & Kurang Baik & $57-70,75$ \\
\hline
\end{tabular}

Sumber: Data Penelitian, 2019.

Berdasarkan output SPSS mengenai analisis deskriptif ini dan interval kategori menyatakan bahwa 89,77 dari hidden curriculum dan 85,56 dari akhlaqul karimah. Dengan demikian peneliti mengambil hipotesis bahwa pengaruh hidden curriculum di SMK Cordova Kajen tahun 2019 tergolong baik karena termasuk 


\section{Nur Laila Syarifah}

dalam interval 87,5 - 97,75 dan pembentukan akhlaqul karimah tergolong cukup baik karena termasuk dalam interval 71,75 -85,5.

Melalui one-sample Kolmogorov-Smirnov test, terlihat angka signifikasnsi untuk variabel hidden curriculum sebesar 0,197 sedangkan variabel akhlaqul karimah sebesar 0,227, yang mana keduanya lebih besar dari 0,05 sehingga kedua variabel tersebut berdistribusi normal.

Selanjutnya dilakukan uji linieritas dengan analisis terhadap scatter plot menggunakan SPSS 17.0 berupa output gambar 1 .

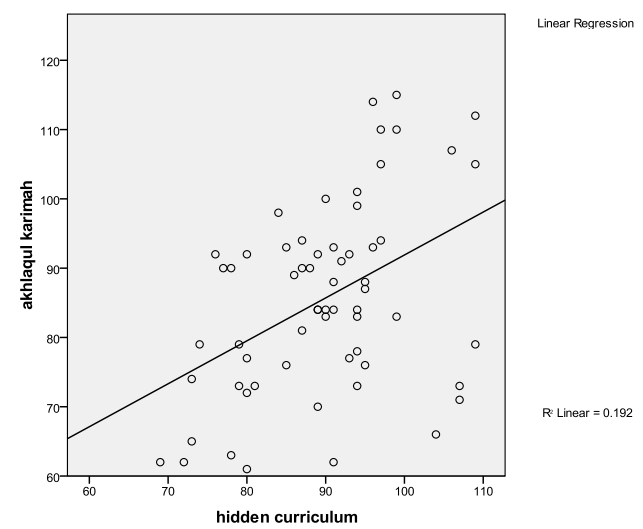

Gambar 1. Grafik Hasil Uji Linearitas Interactive Graph

Berdasarkan grafik di atas terlihat garis regresi pada grafik tersebut mengarah ke kanan atas, ini membuktikan bahwa adanya linearitas pada kedua variabel yaitu hidden curriculum dan akhlaqul karimah, sehingga model regresi tersebut layak digunakan.

Pengujian hipotesis asosiatif yang digunakan untuk menguji hipotesis yang berbunyi: "ada pengaruh antara hidden curriculum terhadap pembentukan akhlaqul karimah siswa di SMK Cordova Kajen tahun 2019" diperoleh persamaan regresinya $\hat{\mathrm{Y}}=29,938+0,62 \mathrm{X}$, diperoleh Fhitung= 14,323 dan Ftabel= 3,15, atau sig. $=$ 0,000. Serta ditunjukkan nilai signifikansi $0,000<0,05$ berarti hidden curriculum berbasis pesantren (X) terhadap pembentukan akhlaqul karimah siswa (Y) di SMK Cordova Kajen Margoyoso Pati Tahun 2018/2019 mempunyai pengaruh yang 


\section{Nur Laila Syarifah}

signifikan. Kesimpulannya adalah H0 ditolak, artinya "terdapat pengaruh yang signifikan antara hidden curriculum berbasis pesantren $(\mathrm{X})$ terhadap pembentukan akhlaqul karimah siswa (Y) di SMK Cordova Kajen tahun 2019”.

Selanjutnya hasil hubungan hidden curriculum dengan pembentukan akhlaqul karimah siswa di SMK Cordova diperoleh rhitung sebesar 0,439, dan selanjutnya dengan tabel pedoman perhitungan korelasi sederhana (Sugiyono, 2015: 257) tergolong "sedang" yaitu terletak pada interval 0,40-0,599. Dengan demikian dapat diinterpretasikan bahwa hidden curriculum berbasis pesantren mempunyai hubungan yang positif dan cukup signifikan dengan pembentukan akhlaqul karimah siswa. Selanjutnya dapat dilihat koefisien determinasi varians yang terjadi pada hidden curriculum dapat dijelaskan melalui varians yang terjadi pada pembentukan akhlaqul karimah, yaitu sebesar 0,1927 atau 19,27\%.

Berdasarkan analisis yang telah peneliti lakukan, hidden curriculum berbasis pesantren di SMK Cordova Kajen tahun 2019 menurut peneliti dikategorikan baik (efektif), yaitu sebesar 89,77 yang termasuk dalam interval 87,597,75. Sedangkan pembentukan karakter akhlaqul karimah siswa di SMK Cordova Kajen tahun 2019 menurut peneliti dikategorikan cukup baik (cukup signifikan), yaitu 85,56 karena termasuk dalam interval 71,5 - 85,5.

Hidden curriculum berbasis pesantren berpengaruh positif dan signifikan terhadap pembentukan karakter akhlaqul karimah siswa di SMK Cordova Kajen Margoyoso Pati tahun 2018/2019, dengan persamaan regresi $\hat{Y}=29,938+0,62$ X. Artinya apabila pelaksanaan hidden curriculum berbasis pesantren ditingkatkan maka karakter akhlaqul karimah pada siswa juga meningkat.

Hidden curriculum berbasis pesantren merupakan suatu hal yang berhubungan dengan pendidikan akhlak dan peran Pendidik dalam mentransformasikan standar akhlak atau internalisasi karakter yang baik. Keberadaan hidden curriculum berbasis pesantren bukan merupakan pengganti kurikulum formal, tetapi merupakan pelengkap dalam mencapai tujuan pendidikan 


\section{Nur Laila Syarifah}

yang telah ditetapkan. Hidden curriculum berbasis pesantren tidak boleh bertentangan dengan kurikulum formal, tetapi dengan format dan model tersendiri harus menjadi pendukung dan pelengkap bagi materi atau pelajaran yang tidak disampaikan dalam kurikulum formal. Keberadaan hidden curriculum berbasis pesantren juga tidak mesti selalu terpisah dengan kurikulum formal, bisa jadi hidden curriculum berbasis pesantren ada ketika kurikulum formal dilaksanakan. Oleh karena itu, pelaksanaan hidden curriculum berbasis pesantren dapat meningkatkan karakter akhlaqul karimah siswa di SMK Cordova Kajen. Sedangkan hubungan antara kedua variabel adalah positif dan cukup signifikan yaitu sebesar 0,439 termasuk dalam kategori sedang. Jadi, hidden curriculum berbasis pesantren memberikan kontribusi sebesar 19,27\% terhadap pembentukan karakter akhlaqul karimah siswa di SMK Cordova Kajen Margoyoso Pati.

\section{Simpulan}

Hidden Curriculum berbasis pesantren di SMK Cordova Kajen tahun 2019 menurut peneliti dikategorikan efektif yaitu dengan nilai sebesar 89,77. Sedangkan pembentukan karakter akhlaqul karimah siswa di SMK Cordova Kajen tahun 2019 menurut peneliti dikategorikan cukup signifikan yaitu dengan nilai sebesar 85,56. Penelitian ini menghasilkan pengaruh yang positif dan signifikan antara hidden curriculum berbasis pesantren dengan pembentukan karakter akhlaqul karimah siswa di SMK Cordova Kajen tahun 2019, dimana apabila hidden curriculum berbasis pesantren meningkat sebesar 1 satuan maka karakter akhlaqul karimah siswa akan meningkat sebesar 0,439. Sehingga hidden curriculum berbasis pesantren memiliki pengaruh sebesar 19,27\% terhadap pembentukan karakter akhlaqul karimah siswa di SMK Cordova Kajen tahun 2019. 
Nur Laila Syarifah

\section{Daftar Pustaka}

Arikunto, Suharsimi. 1998. Prosedur Penelitian Suatu Pendekatan Praktek. Jakarta: Rineka Cipta.

Azizy, A. Qodri A. 2003. Pendidikan (Agama) dalam Membangun Etik Sosial. Semarang: Aneka Ilmu.

Barnawi dan M. Arifin. 2013. Strategi dan Kebijakan, Pembelajaran Pendidikan Karakter. Sleman: Ar-Ruzz Media.

Caswita. 2013. The Hidden Curriculum. Yogyakarta: Leotikaprio.

Dakir. 2010. Perencanaan dan Pengembangan Kurikulum. Jakarta: Rineka Cipta.

Deswita. 2010. Akhlak Tasawuf. Batusangkar : STAIN Batusangkar Press.

Echols, John M. dan Hasan Shadily. 2005. Kamus Inggris-Indonesia, cet XXVI, Jakarta: Gramedia.

Fathoni, Abdurrahmat. 2006. Metodologi Penelitian dan Tehnik Penyusunan Skripsi. Jakarta: PT. Rineka Cipta.

Fatmawati, N., Setyowati, D. L., \& Utomo, C. B. 2018. "Outdoor Study Activity by Utilizing Wonosoco Tourism Village as A Learning Resource of Social Studies". Journal of Educational Social Studies, 7 (1): 88-98.

Firdaus. 2017. "Membentuk Pribadi Berakhlakul Karimah Secara Psikologis". AlDzikra, 11 (1): 55-88.

Halid, Ahmad. 2019. "Hidden Curriculum Pesantren: Urgensi, Keberadaan dan Capaiannya”. Tarbiyatuna: Jurnal Pendidikan Islam, 12 (2): 140-150.

Hasan, Ali, \& Mukti Ali. 2009. Kapita Selekta Pendidikan Agama Islam. Jakarta: Pedoman Ilmu Jaya.

Hidayat, Rakhmat. 2011. Pengantar Sosiologi Kurikulum. Jakarta: Rajawali Pers.

Mulyasana, Dedi. 2012. Pendidikan Bermutu dan Berdaya Saing. Bandung: Remaja Rosdakarya.

Mustaghfiroh, Hikmatul. 2014. "Hidden Curriculum Dalam Pembelajaran PAI", Edukasia: Jurnal Penelitian Pendidikan Islam, 9 (1): 147-162.

Nisa, Kahirun. 2009. "Hidden Curriculum: Upaya Meningkatkan Kecerdasan Spiritual Siswa". Jurnal Lentera Pendidikan, 12 (1): 84.

Pratiwi, Esti Rahma. 2017. "Pengaruh Kurikulum Tersembunyi (Hidden Curriculum) Terhadap Pembentukan Karakter Siswa Di SMP IT Masjid Syuhada' Kotabaru Yogyakarta”. Jurnal Pendidikan Agama Islam, 19 (2): 233-248.

Rosyada, Dede. 2004. Paradigma Pendidikan Denokratis: Sebuah Model Pelibatan Masyarakat Dalam Menyelenggarakan Pendidikan. Jakarta: Prenada Media. 
Nur Laila Syarifah

Sanjaya, Wina. 2008. Kurikulum dan Pembelajaran Teori dan Praktik Pengembangan Kurikulum Tingkat Satuan Pendidikan (KTSP). Jakarta: Kencana Prenada Media. 